\title{
Comparison of three Larval Immersion Tests in Syringe to evaluate acaricidal activity of chemical solutions
}

\section{Comparação entre três técnicas de Imersão de Larvas em Seringas para avaliar atividade acaricida de soluções químicas}

\author{
Juliana Antunes Farias ${ }^{1 *}$; Claudia Cristina Gulias Gomes²; \\ Alessandro Pelegrine Minho ${ }^{2}$; Robert Domingues ${ }^{3}$; Bernardo Macke Franck ${ }^{4}$; \\ Rossana Leitzke Granada ${ }^{4}$; Antonio Pereira de Souza ${ }^{5}$
}

\begin{abstract}
The aim of this study was to compare Larval Immersion Test in syringes, originally proposed by Souza et al. (2008), with two modified bioassays proposed by Silva et al. (2011) and Sindhu et al. (2012). Rhipicephalus (Boophilus) microplus larvae were exposed to nine dilutions of commercial acaricide. After 24 hours, the number of dead larvae was counted. The $\mathrm{LC}_{50}$ for the three methods were $0.186 \%$, $0.125 \%$ and $0.153 \%$, respectively. Mortality of larvae exposed to chemical dilutions on Silva et al. (2011) were significantly higher than other methods at lower concentrations, probably in consequence of longer exposure time of larvae to solutions. However, modifications proposed by Sindhu et al. (2012) make technic execution more practical and safer.
\end{abstract}

Key words: Syringe test. In vitro. Rhipicephalus (Boophilus) microplus.

\section{Resumo}

O objetivo deste trabalho foi comparar a técnica de imersão de larvas em seringas proposta originalmente por Souza et al. (2008), com duas modificações propostas por Silva et al. (2011) e Sindhu et al. (2012). Larvas de Rhipicephalus (Boophilus) microplus foram expostas a nove diluições de acaricida comercial.

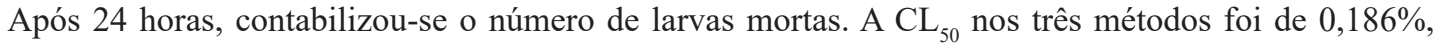
$0,125 \%$ e $0,153 \%$, respectivamente. Houve maior mortalidade de larvas no método de Silva et al. (2011), nas menores concentrações, quando comparado aos demais métodos, provavelmente devido ao maior tempo de exposição das larvas ao composto químico. Entretanto, as modificações propostas por Sindhu et al. (2012) proporcionam maior praticidade e segurança na execução da técnica.

Palavras-chave: Teste em seringa. In vitro. Rhipicephalus (Boophilus) microplus.

\footnotetext{
${ }^{1}$ Discente de Doutorado. Programa de Pós-graduação em Ciência Animal, Centro de Ciências Agroveterinárias, Universidade do Estado de Santa Catarina, PPGCA/CAV/UDESC, Lages, SC, Brasil. E-mail. juliana0807@hotmail.com

2 Pesquisadores, Drs., Setor de Sanidade Animal, Embrapa Pecuária Sul, Bagé, RS, Brasil. E-mail: claudia.gulias@embrapa.br; alessandro.minho@embrapa.br

3 Analista, M.e Setor de Sanidade Animal. Embrapa Pecuária Sul, Bagé, RS, Brasil. E-mail: robert.domingues@embrapa.br

4 Técnicos, Setor de Sanidade Animal. Embrapa Pecuária Sul, Bagé, RS, Brasil. E-mail: bernardo.franck@embrapa.br; rossana. granada@embrapa.br

5 Prof. Dr., Visitante Sênior, Instituto Federal Catarinense, IFC, Campus de Araquari, Bolsista PVNS/CAPES, e Prof. Voluntário Programa de Pós-graduação em Ciência Animal, UDESC, Lages, SC, Brasil. E-mail: antonio.souza@ifc-araquari.edu.br

* Author for correspondence
} 
Chemical control of Rhipicephalus (Boophilus) microplus in Brazil is going through a critical moment of scarcity of still effective classes of drugs. The search for new active molecules has tempted studies on acaricidal effect of plant extracts. At present in vitro bioassays are currently used as screening tests. Souza et al. (2008) developed a method based on Larvae Immersion Test, first described by (SHAW, 1966). The method replaces the microtube by syringes making the original technic less laborious. The bioassay described by Souza et al. (2008) has been changed to evaluate plant extracts acaricide effect in Brazil and abroad (SILVA et al., 2011; SINDHU et al., 2012). This paper aimed to compare the proposed adaptations to the original method. Souza et al. (2008) method consists in immersing $5 \mathrm{~mL}$ syringe in test solution to submerge tick larvae for 30 seconds. Acaricidal effect is determined counting the number of live and dead larvae 24 hours after exposition. Syringes used in the bioassay are prepared cutting the nozzle and making an orifice of $1 \mathrm{~mm}$ of diameter in the middle of the syringe to permit scape of air and liquid entrance. The opened end is sealed with nylon fabric before the immersion to prevent escape of larvae. Change adopted by Silva et al. (2011) consisted of increasing time of larvae immersion from 30 seconds to five minutes. The method described by Sindhu et al. (2012) adds the standard volume of two milliliters of test solution into syringes of $3 \mathrm{~mL}$ containing the larvae. Test solution is discarded by pushing the plunger up to the gauze, eliminating the need for air exhaust orifice.

Immersion Tests were carried out with $R$. (B.) microplus kept on cattle free of hemoparasites at Embrapa South Livestock. All animal procedures were approved by the Santa Catarina State University Institutional Animal Care and Use
Committee. Engorged females were stored in incubator at $27^{\circ} \mathrm{C}$ and $80 \%$ relative humidity (RH) and eggs transferred to $20 \mathrm{~mL}$ syringes. Groups of 100 active larvae, from 10 to 15 -day-old, were transferred to syringes tests 24 hours before the bioassay and syringes incubated in the dark at $27{ }^{\circ} \mathrm{C}$ and $80 \% \mathrm{RH}$. A system that connects the syringe test to oil-less vacuum and pressure pump was developed to transfer larvae to syringe test and to count larvae at the end of exposure time (Figure 1). Methods were compared exposing larvae to a chemical composition of cypermethrin (15\%), chlorpyrifos (25\%) and piperonyl butoxide (1\%) (Texvet $^{\circledR}$ - Agroline) prepared in nine serial dilutions $(100,25 ; 6.25 ; 1.56 ; 0.39 ; 0.19 ; 0.09$; 0.02 and $0.006 \%$ ). The highest concentration was prepared as recommended by the manufacturer (1 $\mathrm{mL}: 1$ Liter or $150 \mathrm{ppm}$ of cypermethrin: $250 \mathrm{ppm}$ of chlorpyrifos). Each treatment consisted of six replicates.

After larvae exposure to solutions, syringes were dried on paper towels, kept for one hour in fume hood and transferred to a room at $27{ }^{\circ} \mathrm{C}$ and $80 \%$ RH. Percent mortality was calculated to each concentration 24 hours later, considering as dead the larvae without motility. Results were submitted to analysis of variance followed by the comparison of means through randomized blocks. Percent mortality and median lethal concentration $\left(\mathrm{LC}_{50}\right)$ of each treatment was corrected by control means groups, exposed to distilled and deionized water, according to (ABBOTT, 1925). $\mathrm{LC}_{50}$ was calculated in GraphPad Prism (V. 6.05, 2014) after transforming acaricide concentrations in $\operatorname{logarithm}(\mathrm{x}=\log (\mathrm{x}))$. Slope of the dose-response curve was defined as variable, and maximum and minimum mortality defined as hundred and zero, respectively. 
Figure 1. Vacuum and pressure system used for transferring storage Rhipicephalus (Boophilus) microplus larvae to syringes test (A) and to count larvae at the end of exposure time in Larvae Immersion Test (B). The vacuum or pressure pump function was alternated to suck or expel larvae, as needed during the bioassay.

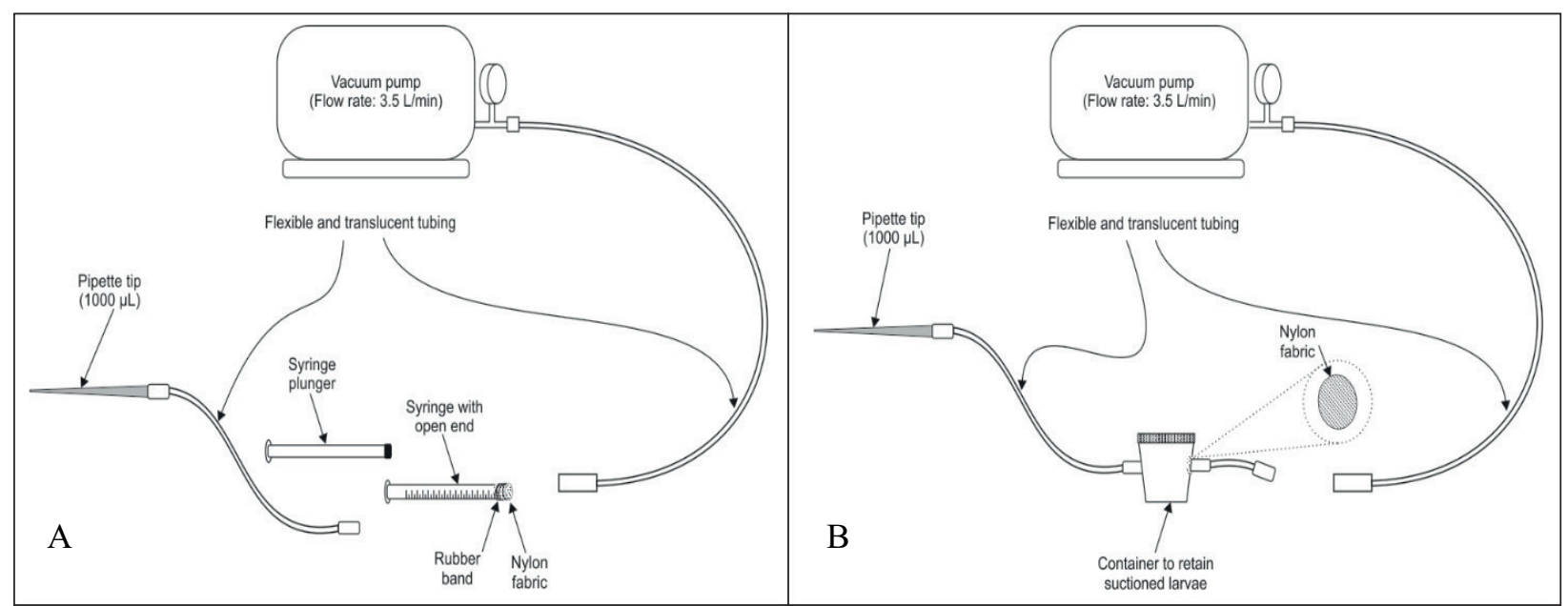

Source: (ALVES, 2014).

Larvae mortality was directly proportional to increase of acaricidal concentration for the three methods (Figure 2). Control mortality did not exceed $5 \%$ in all treatments. Mortality in distilled and deionized water was higher in Silva et al. (2011) method $(1.48 \% \pm 0.79$, mean $\pm \mathrm{SE})$, followed by Sindhu et al. (2012) $(0.57 \pm 0.41)$ and Souza et al. (2008) (0.33 \pm 0.17$)$. Mortality of larvae exposed to chemical dilutions on Silva et al. (2011) were significantly higher than other methods at lower concentrations (Figure 2), probably in consequence of longer exposure time of larvae to solutions. Values of $\mathrm{LC}_{50}$ were $0.125 \%$, $0.153 \%$ and $0.186 \%$ for Silva et al. (2011), Sindhu et al. (2012) and Souza et al. (2008) methods, respectively.

Figure 2. Acaricidal activity of chemical solutions containing cypermethrin and chlorpyrifos on larvae of Rhipicephalus (Boophilus) microplus evaluated by Larvae Immersion Techniques in syringes described by Souza et al. (2008), Silva et al. (2011) and Sindhu et al. (2012).

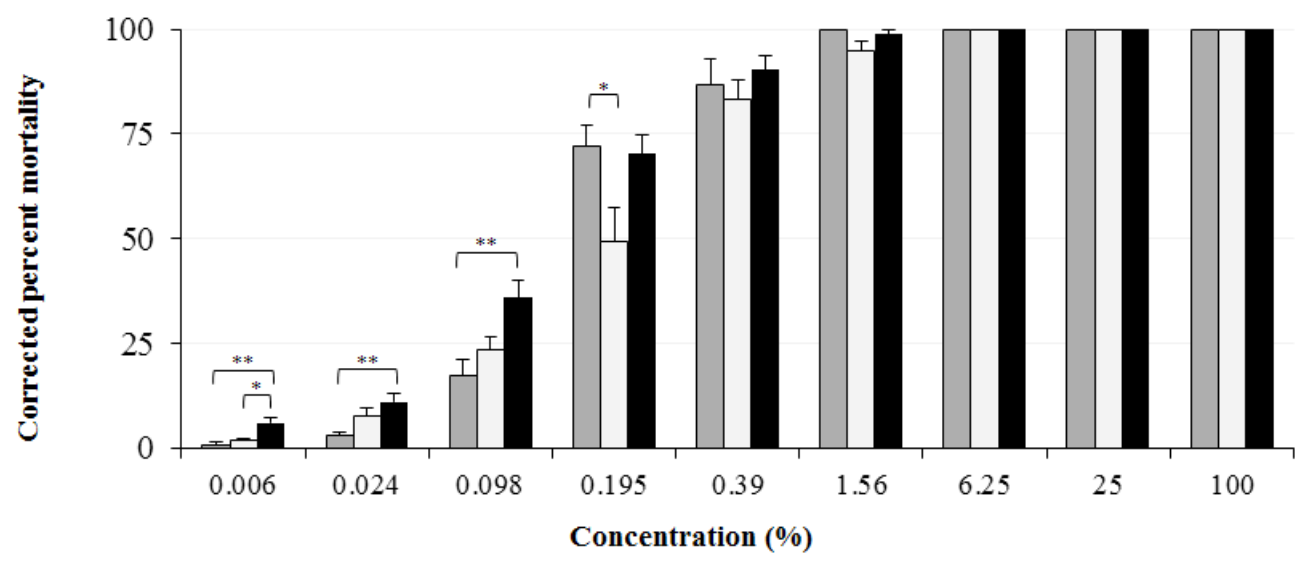

$\square$ Sindhu et al. $\quad \square$ Souza et al. $\quad$ Silva et al.

$* \mathrm{p}<0.05 ; * * \mathrm{p}<0.01$ 
Changes proposed by Silva et al. (2011), increasing larva immersion time from 30 seconds to 5 minutes, lead to lower $\mathrm{LC}_{50}$. Sindhu et al. (2012) modifications make the test safer and more practical since (i) reduces syringes preparation time, (ii) reduces space required for syringe storage (the $3 \mathrm{~mL}$ syringe is used instead of a 5 $\mathrm{mL}$ ), (iii) decreases the risk of environment and the handler contamination with the test solution (volume prepared is reduced and discharge process is cleaner) and (iv) saves solution (only $2 \mathrm{~mL}$ of solution by replication).

From the three evaluated methods, the use of $3 \mathrm{~mL}$ syringes without an orifice, 30 seconds immersion time and the standard of two milliliters of test solution into each syringe make larval immersion test in syringe less laborious, without losing results reliability.

\section{Acknowledgments}

We are thankful to Roberto Cimirro Alves who kindly drew Figure 1. This study was supported by Brazilian Agricultural Research Corporation (Embrapa) and Coordination for the Improvement of Higher Level Personnel (CAPES, grant 41002016008P-3).
This study was approved by the Ethics Committee on Animal Experiments (CETEA) of the University of Santa Catarina State (UDESC) under protocol number 01.59.14.

\section{References}

ABBOTT, W. S. A method of computing the effectiveness of an insecticide. Journal Economic Entomology, Annapolis, v. 18, n. 2, p. 265-267, 1925.

SHAW, R. D. Culture of an organophosphorus-resistant strain of Boophilus microplus (Can) and an assessment of its resistance spectrum. Research Entomology Bull, New York, v. 56, n. 3, p. 389-405, 1966.

SILVA, W. C.; MARTINS, J. R. de S.; CESIO, M. V.; AZEVEDO, J. L.; HEINZEN, H.; BARROS, N. M. B. Acaricidal activity of Palicourea marcgravii, a species from the Amazon forest, on cattle tick Rhipicephalus (Boophilus) microplus. Veterinary Parasitology, Amsterdam, v. 179, n. 1, p. 189-194, 2011.

SINDHU, Z. U. D. D.; JONSSON, N. N.; IQBAL, $Z$. Syringe test (modified larval immersion test): A new bioassay for testing acaricidal activity of plant extracts against Rhipicephalus microplus. Veterinary Parasitology, Amsterdam, v. 188, n. 3, p. 362-367, 2012.

SOUZA, A. P.; VEIGA, L. P. H. N.; BELLATO, V.; SARTOR, A. A.; CARDOSO, C. P.; NUNES, A. P. de O. Proposta para teste carrapaticida por imersão de larvas de Rhipicephalus (Boophilus) microplus: avaliação em cipermetrina e amitraz. Revista Brasileira de Parasitologia Veterinária, Jaboticabal, v. 17, n. 4, p. 242-245, 2008. 